\title{
EFFECT OF CORPORATE GOVERNANCE PRACTICES ON R\&D AND INNOVATION COSTS: A CASE STUDY ON BORSA ISTANBUL*
}

Prof. Dr. Hüseyin Ali KUTLU ${ }^{a}$ Arş. Gör. Dr. Bekir GEREKAN ${ }^{b}$

Ampirik Araştırma

(Empirical Research)
Muhasebe ve Vergi

Uygulamaları Dergisi

Kasim 2021; 14 (3): 967-994

\begin{abstract}
This study aimed to reveal the impact of corporate governance practices (CGP) on research and development (R\&D) expenses and innovation costs. The businesses registered in Borsa Istanbul (BIST), with complete data regarding R\&D and innovation costs for 2009-2017, were analyzed. The panel regression analysis performed through the STATA 15.0 program revealed that the board size, number of independent board members, gender diversity in the board of directors, chairman's tenure, board meeting frequency, and business scale had a statistically significant and positive effect on the realized R\&D expenses. Furthermore, it was determined that the number of foreign members of the board of directors, board ownership, and the organizational age had a statistically significant and negative effect on the nominal R\&D expenses. However, it was also discovered that the role duality and business scale had a statistically significant and positive impact. In contrast, the foreign member ratio on the board of directors and organizational age had a statistically significant and negative effect on innovation costs.
\end{abstract}

Keywords: Corporate Governance, Innovation Costs, R\&D Expenses, R\&D, Innovation.

JEL Codes: M40, M41, M49.

APA Stili Kaynak Gösterimi:

Kutlu, H. A., Gerekan, B. (2021). Effect of Corporate Governance Practices on R\&D and Innovation Costs: A Case Study on Borsa İstanbul. Journal of Accounting and Taxation Studies. 14 (3), 967-994.

\footnotetext{
* Makalenin gönderim tarihi: 29.04.2021; Kabul tarihi: 01.07.2021, iThenticate benzerlik oranı \%12 ${ }^{a}$ Atatürk Üniversitesi, İktisadi ve İdari Bilimler Fakültesi, huseyinalikutlu@gmail.com ORCID: 0000-0001-7764-0768.

${ }^{b}$ Ağr İbrahim Çeçen Üniversitesi, İktisadi ve İdari Bilimler Fakültesi, bgerekan@agri.edu.tr ORCID: 0000-0001-6724-4729.
}

Muhasebe ve Vergi Uygulamaları Dergisi 


\section{KURUMSAL YÖNETIM UYGULAMALARININ AR-GE VE INOVASYON MALIYETLERİ ÜZERINDEKİ ETKISİ: BORSA İSTANBUL' DA BİR ARAȘTIRMA}

\section{$\ddot{\mathrm{oz}}$}

Hazırlanan çalışmanın amacı, kurumsal yönetim uygulamalarının Ar-Ge giderleri ve inovasyon maliyetleri üzerindeki etkisini incelemektir. Bu amaç doğrultusunda, Borsa İstanbul'a (BIST) kayıtlı işletmelerden 2009 - 2017 yıllarına ait Ar-Ge ve inovasyon maliyetleri eksiksiz şekilde elde edilen işletmeler analiz kapsamında incelenmiştir. STATA 15.0 programı kullanılarak gerçekleştirilen panel regresyon analizine göre; yönetim kurulu büyüklüğünün, bağımsız üye sayısının, cinsiyet çeşitliliğinin, yönetim kurulu başkanı görev süresinin, yönetim kurulu toplantı sıklığının ve işletme büyüklügünün gerçekleşen Ar-Ge giderleri üzerinde istatistiksel açıdan anlamlı ve pozitif etkiye sahip olduğu görülmüştür. Ayrıca yönetim kurulu yabancı üye sayısı, yönetim kurulu sahipliği ve işletme yaşının ise ortaya çıkan Ar-Ge giderleri üzerinde istatistiksel açıdan anlamlı ve negatif etkiye sahip olduğu tespit edilmiştir. Bununla birlikte inovasyon maliyetleri üzerinde etkilerinin incelendiği rol ikiliği ve işletme büyüklüğünün istatistiksel açıdan anlamlı ve pozitif, yönetim kurulu yabancı üye oranı ve işletme yaşının ise inovasyon maliyetleri üzerinde istatistiksel açıdan anlamlı ve negatif etkiye sahip olduğu tespit edilmiştir.

Anahtar Sözcükler: Kurumsal Yönetim, İnovasyon Maliyetleri, Ar-Ge Giderleri, Ar-Ge, İnovasyon.

JEL Kodları: M40, M41, M49.

\section{INTRODUCTION ${ }^{1}$}

Corporate scandals, economic crises and bankruptcies on a global scale have created new challenges and crystallized the fundamental role of corporate management systems. It is arguable that the corporate governance (CG) understanding, including a broad framework from corporate image to shareholder rights protection with various applications, has become an integral part of the business world in developed countries.

However, the effective management of raw information and innovation is adapted to $\mathrm{CG}$ visions in economies with highly competitive environments. It can be stated that this interaction indirectly affects the innovation capabilities of enterprises. These innovation capabilities are usually assessed by the importance level that businesses attach to research and development (R\&D) activities and new technological processes. The pressing puzzle is about how CG practices (CGPs) affect the innovation capabilities and R\&D activities of enterprises.

This study aimed to determine the effects of CGPs shaped by a company's economic, legal, and social characteristics on R\&D expenses and innovation costs in the case of Borsa İstanbul (BIST). The CG, R\&D, and innovation

\footnotetext{
${ }^{1}$ This study derived from the doctoral thesis titled "The Effect of Corporate Governance Practices on R\&D and Innovation Costs: A Research in Borsa Istanbul" prepared by Bekir GEREKAN under the consultancy of Prof. Dr. Hüseyin Ali KUTLU.
} 
concepts will be briefly discussed in the following sections. The study will elaborate on the general assessments about the empirical findings obtained from the panel regression analysis followed by the findings, conclusion, and suggestions.

\section{CORPORATE GOVERNANCE, R\&D AND INNOVATION}

\subsection{Corporate Governance}

Recent studies have defined the CG concept as a "holistic complex of interactions between the board, shareholders, and external partners" (OECD 2015: 9).

Various definitions of this concept can be found in the literature. Luo (2005: 2) defined the concept of CG as a bilateral relationship that strategically examines and controls the relationship between the business and its shareholders. Cuervo (2002: 84) conceptualized CG as a system that protects shareholders and other stakeholders from the discretionary power of management, while Ahlering and Deakin (2007: 876) defined it as a mechanism that reduces agency costs and maximizes business wealth. Furthermore, Sternberg (1998: 28) explained the concept of CG as the power that enables corporate activities, business assets and executive representatives to be directed towards achieving the corporate goals determined by the organization's shareholders.

The concept of CG has been a subject of research on management since the early 1980s. However, this concept changed through the studies conducted in the first half of the 1990s, as it evolved into a concept that includes business planning and internal processes (Forbes and Milliken, 1999: 498499). Moreover, the concept experienced another transformation since the first half of the 2000s. The alternative approach of CG now includes management elements that can be effective in increasing the business performance and ensuring investor confidence (Reed, 2002: 228-232).

\section{2. $R \& D$ and Innovation}

In the global world order, technology and knowledge have become a priority in achieving sustainable competitive power (OECD, 1999). Technological innovations emerging as a result of $R \& D$ and innovation activities carried out on behalf of countries and enterprises play an essential role in achieving the desired competitive advantage.

There are numerous definitions in the literature regarding $R \& D$ and innovation concepts. These concepts are depicted in different ways according to their intended use and user preferences. According to the Accounting System Application General Communiqué, published in the Official Gazette dated 26/12/1992 and numbered 21447, R\&D is the

Muhasebe ve Vergi Uygulamaları Dergisi 
activities performed to reduce production-related costs and increase sales, and adopt modern production methods. An alternative perspective argued that $R \& D$ is an effort that enables the provision of unique productions depending on the development and renewal of ideas regarding the existing structure. (Fidanc1, 2017: 72). Thus, the concept of R\&D can be expressed as the set of systematic efforts that enable the transformation of the knowledge into outputs that will provide added value for the organization.

On the other hand, the concept of innovation is derived from the word 'innovare' or 'innovates', originating from Latin (Başaran and Keleş, 2015: 106). This concept essentially means "doing something new" (Lin and Ho, 2007: 2). It is possible to describe this concept as revealing the non-existent in the market or improving the existing one in terms of process, service, or product (Bentz, 1997: 12).

R\&D activities are vital in the innovation attempts of enterprises. However, it is not possible to say that all innovation outputs occur through R\&D activities. Therefore, it is possible to say that the concept of $R \& D$ is one of the elements under the roof of innovation (Şahin, 2004: 262).

\section{LITERATURE REVIEW}

There are several studies in the literature on CGPs. Most of the studies on the subject are on the correlation between CGPs and financial performance (Ahmed and Hamdan, 2015; Balsar1 et al. 2015; Kara et al. 2015; Labelle et al. 2015; Singh, 2015; Aytekin and Sönmez, 2016; Otluoğlu et al. 2016; Terjesen et al. 2016; Atılgan, 2017; Gunnarsson et al. 2017; Taşkın and Mandac1, 2017; Talavera et al. 2018).

Though there is little research on the correlation between CGP and R\&D and innovation investments. Recent studies that have examined this phenomenon are summarized below.

The results of studies on the impact of the institutional investor level on R\&D investments vary. In some studies conducted on the subject it has been stated that the increases occurring at the institutional investor level, which has business shares, positively affect R\&D and innovation investments (Eng and Shackell, 2001; Tribo et al. 2007; Choi et al. 2011; Lhuillery, 2011; Choi et al. 2012; Aghion et al. 2013; Brossard et al. 2013; Setayesh et al. 2016; Doğan and Tiryakioğlu, 2018). Moreover, it was revealed as a result of these studies that this situation negatively affects R\&D and innovation investments (Graves and Waddock, 1990; Ren et al., 2012; Cebula and Rossi, 2015; Lee, 2015; Minetti et al. 2015). Moreover, there are previous studies on the effects of the organizational investor level on R\&D and innovation investments with findings that proved a statistically insignificant impact (Lee, 2012; Singh and Gaur, 2013).

Muhasebe ve Vergi Uygulamaları Dergisi 
The board size and the number of independent board members are among the analyzed CGPs regarding R\&D and innovation investments. Previous studies provided divergent results regarding the effects of both the number of members and independent members on the board of directors on business performance. Some previous studies concluded that these variables affect R\&D and innovation investments positively (Zhaohui and Ding, 2012; Shapiro et al. 2015; Ashwin et al. 2016; Chen et al. 2016; Chou, 2017). However, there are also arguments on this effect with a contrary direction (Mat Rabi et al. 2010; Chen, 2012; Ren et al. 2012; Zhaohui and Ding, 2012; Shapiro et al. 2015; Setayesh et al. 2016).

Furthermore, it was observed that contradictory results were reached in studies on the effects of the number of meetings held by the board of directors during a fiscal period and role duality on $R \& D$ and innovation investments. Donaldson and Davis (1991), Finkelstein and D'Aveni (1994), Mat Rabi et al. (2010), Ntim and Osei (2011), Chen (2012), and Chou (2017) discovered that the number of board meetings and role duality factors have positive effects on R\&D and innovation investments. However, Rechner and Dalton (1991), Mallette and Fowler (1992), and Ren et al. (2012) stated the contrary. Moreover, Mat Rabi et al. (2010), Coles et al. (2001), Zhaohui and Ding (2012), and Shapiro et al. (2015) found that these CGPs did not have a statistically significant effect on R\&D and innovation investments.

Certain schools of thought have also focused on the impact of the number of female members on the board of directors, which is one of the CGPs, on $R \& D$ and innovation investments. Recent studies have placed reservations on the mentioned variables regarding their positive effects on $R \& D$ investments (Talke et al. 2010; Torchia et al. 2011; Østergaard et al. 2011; Pfeifer and Wagner, 2012; Jiménez and Fuentes, 2015; Teruel et al. 2015; Galia and Zenou, 2012). Moreover, there are also studies in contemporary thought that have stated that the current effect level is negative (García and Velasco, 2016).

It is possible to assert that this study obtained similar results with the studies on the effects of foreign member ratio on the board of directors and the chairman's tenure on R\&D and innovation investments. Barker and Mueller (2002) found that a longer chairman's tenure at the board increased the impact on these expenditures, as the chairmen gradually directed the $R \& D$ expenditures based on their preferences. Similar results were propounded by Mezghanni (2010) as well, who stated that R\&D investments increase during the first 15 years depending on the chairman's tenure at the board, as the chairmen begin to adopt investment-oriented attitudes with reductions in the relevant expenditures. Cucculelli (2018) further elaborated on studies conducted by Barker and Mueller's (2002) and Mezghanni (2010) and investigated the effects of the chairman's tenure on R\&D and innovation

Muhasebe ve Vergi Uygulamaları Dergisi 
investments depending on the organizational age. It was determined that there was a positive correlation between the chairman's tenure at the board of directors and innovation performance in enterprises where the organizational age was between 20 and 39 years. However, it was stated that this correlation was negative in businesses where the organizational age was 40+ years. On the other hand, Midavaine et al. (2016) determined that the chairman's tenure had a negative impact on these investments. Moreover, a positive relationship was found in studies examining the impact of the number of foreign members on the board of directors on $R \& D$ and innovation investments to be carried out by enterprises (Miller and Triana 2009; Makkonen et al. 2018).

\section{METHODOLOGY}

\subsection{Subject and Purpose of the Research}

There are several studies in the literature examining the impact of CGPs on financial performance. However, the research on the impact of CGPs on $R \& D$ or innovation costs is very limited. These studies are mostly in English, and there are very few studies on the subject in Turkish. However, it has been observed that CGPs are usually generalized by including only one or two elements, both in local and international studies. Therefore, there is an epistemological gap in the literature.

The aim of this study was to examine the impact of corporate CGPs shaped by the economic, legal, and social characteristics of enterprises registered in BIST on R\&D expenses and innovation costs.

The corporate elements of all of the enterprises (BIST All Enterprises group) in BIST were determined and the impact of these elements on R\&D expenses and innovation costs were examined. The indicators considered as a basis for the CG characteristics of the enterprises were determined by examining the studies in the literature. The indicators were determined from the most preferred variables in measuring CGPs.

This study differentiated itself by the measurement of R\&D expenses and innovation costs in accordance with the TAS 38 Intangible Fixed Assets Standard and by addressing the effects of CGPs on R\&D expenses and innovation costs separately. Therefore, it is believed that the findings will contribute to the literature.

\subsection{Research Method}

The panel data analysis method was used in this study to analyze the impact of CGPs on R\&D expenses and innovation costs. The main reason behind this methodological approach was that the panel data analysis method allows more effective research through both time series and cross-section 
data together. STATA 15.0 (StataCorp LLC, College Station, TX, USA) was used for the data analysis.

\subsection{Data Set, Sample, and Boundaries of the Study}

The first data set of the analysis was created from the financial statement data of 513 enterprises in the BIST All Enterprises group that were disclosed to the public between 2009 and 2017. These data were obtained from the official website of the Public Disclosure Platform (PDP).

The second data set was related to the CG features of the enterprises. These data were obtained from the activity reports of the enterprises, CG principles, compliance reports, and the websites of the enterprises.

However, this study had certain limitations. First, the research findings could only be generalized for companies that traded on the BIST. Second, the data only covered the years from 2009 to 2017 for the selected enterprises. The continuous data on R\&D expenses in 76 of the 513 companies in BIST were obtained for this period. Moreover, the continuous data for the capitalized development costs between 2009 and 2017 were only available for 22 of the 513 enterprises in total. Furthermore, continuous data on the variable of board meeting frequency were available for 41 businesses. The fact that all 513 enterprises in BIST were not available for use in the analysis was yet another limitation in the process.

\subsection{Research Variables}

Three models were developed for the application stage of the study. A total of 13 variables, including 2 dependent variables (DVs), 9 independent variables (IVs), and 2 control variables (CVs), were used. Detailed explanations of the mentioned variables are provided in the following section. 
Table 1: Variables of the Research

\begin{tabular}{|c|c|c|c|c|}
\hline Variable Type & Variable & References & Calculation Method & Symbol \\
\hline \multirow{2}{*}{$\begin{array}{c}\text { Dependent } \\
\text { Variable (DV) }\end{array}$} & “R\&D Expenses" & $\begin{array}{l}\text { "Kocamış and Güngör (2014), } \\
\text { Cebula and Rossi (2015)". }\end{array}$ & $\begin{array}{l}\text { "R\&D Expenses } \\
\text { Logarithm" }\end{array}$ & $\mathrm{R} \& \mathrm{D}$ \\
\hline & "Innovation Costs" & $\begin{array}{l}\text { "Littkemann (1996), Kostellou and } \\
\text { Tsakiri (2010), Dainien and } \\
\text { Dagiliene (2014), Yangfan (2015), } \\
\text { Labunska et al. (2017)". }\end{array}$ & $\begin{array}{l}\text { "Capitalized } \\
\text { Development Costs } \\
\text { Logarithm"2 }\end{array}$ & Inv_Mlyt \\
\hline \multirow{9}{*}{$\begin{array}{l}\text { Independent } \\
\text { Variable (IV) }\end{array}$} & $\begin{array}{l}\text { "Independent Board } \\
\text { Member" }\end{array}$ & $\begin{array}{l}\text { “Chau \& Gray (2010), Müller } \\
\text { (2014), Liao et al. (2015), } \\
\text { Akdoğan et al. (2017), Ben-Amar } \\
\text { et al. (2017), Sword and North } \\
\text { (2019)”. }\end{array}$ & $\begin{array}{l}\text { "Number of Independent } \\
\text { Board Members/Total } \\
\text { Number of Board } \\
\text { Members" }\end{array}$ & IBM \\
\hline & $\begin{array}{l}\text { "Board Meeting } \\
\text { Frequency" }\end{array}$ & $\begin{array}{l}\text { "Laksmana (2008), Ntim and Osei } \\
\text { (2011), Chen (2012), Ocak and } \\
\text { Özden (2017), AlQudah et al. } \\
\text { (2019)". }\end{array}$ & $\begin{array}{l}\text { "Total Number of Board } \\
\text { Meetings Logarithm" }\end{array}$ & BMF \\
\hline & $\begin{array}{l}\text { "Corporate } \\
\text { Ownership" }\end{array}$ & $\begin{array}{l}\text { "Chang et al. (2008), Laksmana } \\
\text { (2008), Samaha et al. (2012), } \\
\text { Juhmani (2013), Soliman et al. } \\
\text { (2014), Lee (2015)". }\end{array}$ & $\begin{array}{l}\text { "Corporate Investors } \\
\text { Percentage" }\end{array}$ & $\mathrm{CO}$ \\
\hline & $\begin{array}{l}\text { "Board of Directors } \\
\text { Ownership" }\end{array}$ & $\begin{array}{l}\text { "Demsetz and Villalonga (2001), } \\
\text { Eng and Mak (2003), Fauzi and } \\
\text { Locke (2012), Bhagat and Bolton } \\
(2013) \text { ". }\end{array}$ & $\begin{array}{l}\text { "Board Members' Share } \\
\text { Percentage in the } \\
\text { Capital" }\end{array}$ & BDO \\
\hline & $\begin{array}{l}\text { "Foreign Members } \\
\text { Percentage in the } \\
\text { Board of Directors" }\end{array}$ & $\begin{array}{l}\text { "Ujunwa et al. (2012), Kilıç } \\
\text { (2014), Sunday and Godvin } \\
\text { (2017), AlQudah et al. (2019), } \\
\text { Okere et al. (2019)". }\end{array}$ & $\begin{array}{l}\text { "Number of Independent } \\
\text { Board Members/Total } \\
\text { Number of Board } \\
\text { Members" }\end{array}$ & FMPBD \\
\hline & "Board Size" & $\begin{array}{l}\text { "Cheng \& Courtenay (2006), } \\
\text { Laksmana, (2008), Samaha et al. } \\
\text { (2012), Uyar et al. (2013), Müller } \\
\text { (2014)". }\end{array}$ & $\begin{array}{l}\text { "Total Number of } \\
\text { Members on the Board } \\
\text { of Directors Logarithm" }\end{array}$ & BS \\
\hline & "Role Duality" & $\begin{array}{l}\text { "Chang et al. (2008), Aygün and İç } \\
\text { (2010), Mezghanni (2010), Doğan } \\
\text { et al. (2013) and Kilıç (2014)". }\end{array}$ & $\begin{array}{c}\text { " } 1 \text { if the General } \\
\text { Manager is also the } \\
\text { Chairman of the Board, } \\
0 \text { otherwise" }\end{array}$ & RD \\
\hline & $\begin{array}{l}\text { "Chairman's } \\
\text { Tenure" }\end{array}$ & $\begin{array}{l}\text { "Golden and Zajac (2001), Vafeas } \\
\text { (2003), Musteen et al. (2006), } \\
\text { Mezghanni (2010)". }\end{array}$ & $\begin{array}{l}\text { "Term of Office for the } \\
\text { Chairman of the Board } \\
\text { Logarithm" }\end{array}$ & $\mathrm{CT}$ \\
\hline & $\begin{array}{l}\text { "Gender Diversity } \\
\text { in the Board of } \\
\text { Directors" }\end{array}$ & $\begin{array}{l}\text { "Barako and Brown (2008), } \\
\text { Rupley et al. (2012), Müller } \\
\text { (2014), Liao et al. (2015), Ben- } \\
\text { Amar et al. (2017)". }\end{array}$ & $\begin{array}{l}\text { "The Female Member } \\
\text { Number Board of } \\
\text { Directors/Total Number } \\
\text { of Board of Directors } \\
\text { Number of Members" }\end{array}$ & GDBD \\
\hline
\end{tabular}

2"It is the calculation used under the Chart of Accounts Compliant with Financial Reporting Standards published by the Public Oversight, Accounting and Auditing Standards Authority (PO) on 31/12/2018". 
Table 1 includes the calculation methods and symbol representations of the DVs and IVs. Moreover, the information is available about cited studies for each variable.

Table 2: Control Variables

\begin{tabular}{|c||c|c|c|}
\hline Variable Type & Variable & Calculation Method & Symbol \\
\hline \multirow{2}{*}{$\begin{array}{c}\text { Control Variables } \\
(\mathbf{C V})\end{array}$} & "Business scale" & "Total Assets Logarithm" & BS \\
\cline { 2 - 4 } & $\begin{array}{c}\text { "Organizational } \\
\text { Age" }\end{array}$ & $\begin{array}{c}\text { "The Registered Period to BIST } \\
\text { Logarithm" }\end{array}$ & OA \\
\hline
\end{tabular}

Several studies on CG features have found that CVs that can affect the general functions of the enterprises are widely used. Therefore, BS and OA were determined to be a CV.

\subsection{Research Model and Hypotheses}

Below are the 3 panel data models applied in the research.

\section{Model 1:}

$\mathrm{R}_{2} \mathrm{D}_{\mathrm{it}}=\beta 0+\beta 1 I B M_{i t}+\beta 2 G D B D_{i t}+\beta 3 C O_{i t}+\beta 4 B S_{i t}+\beta 5 R D_{i t}+\beta 6$ $F M P B D_{i t}+\beta 7 C T_{i t}+\beta 8 B D O_{i t}+\beta 9 B S_{i t}+\beta 10 O A_{i t}+u_{i t}$

\section{Model 2:}

Inv_Mlyt $_{i t}=\beta 0+\beta 1 B S_{i t}+\beta 2 R D_{i t}+\beta 3 F M P B D_{i t}+\beta 4 B D O_{i t}+\beta 5 B S_{i t}$ $+\beta 6 O A_{i t}+u_{i t}$

\section{Model 3:}

$\mathrm{R} \& \mathrm{D}_{\mathrm{it}}=\beta 0+\beta 1 I B M_{i t}+\beta 2 G B P D_{i t}+\beta 3 B S_{i t}+\beta 4 R D I_{i t}+\beta 5 F M P B D_{i t}$ $+\beta 6 C T_{i t}+\beta 7 B D O_{i t}+\beta 8 B S_{i t}+\beta 9 O A_{i t}+\beta 10 B M F_{i t}+u_{i t}$ 
Table 3: Research Hypotheses

\begin{tabular}{|c|c|}
\hline Hypothesis & Explanation \\
\hline 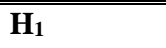 & "Corporate ownership level has a statistically significant effect on R\&D expenses." \\
\hline $\mathbf{H}_{2 \mathrm{~A}}$ & $\begin{array}{l}\text { "The board members' share level in the capital has a statistically significant effect } \\
\text { on R\&D expenses". }\end{array}$ \\
\hline $\mathbf{H}_{2 \mathbf{B}}$ & $\begin{array}{l}\text { "The board members' share level in the capital has a statistically significant effect } \\
\text { on Innovation Costs." }\end{array}$ \\
\hline $2 \mathbf{H}_{3 \mathbf{A}}$ & "Board size has a statistically significant effect on R\&D expenses." \\
\hline 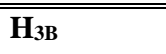 & "Board size has a statistically significant effect on Innovation Costs." \\
\hline $\mathbf{H}_{4}$ & $\begin{array}{l}\text { "The independent board members ratio has a statistically significant effect on R\&D } \\
\text { expenses." }\end{array}$ \\
\hline 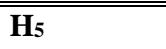 & "Board meeting frequency has a statistically significant effect on R\&D expenses." \\
\hline$\overline{H_{6 A}}$ & "Role duality has a statistically significant effect on R\&D expenses." \\
\hline 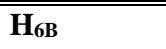 & "Role duality has a statistically significant effect on Innovation Costs." \\
\hline $\mathbf{H}_{7}$ & 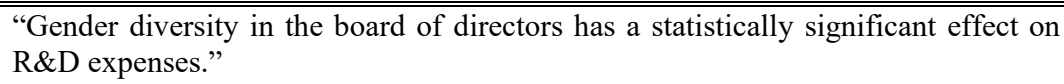 \\
\hline $\mathbf{H}_{8 \mathbf{A}}$ & $\begin{array}{l}\text { "The independent board members ratio has a statistically significant effect on R\&D } \\
\text { expenses." }\end{array}$ \\
\hline $\mathbf{H}_{8 \mathrm{~B}}$ & $\begin{array}{l}\text { "The foreign member ratio on the board of directors has a statistically significant } \\
\text { effect on Innovation Costs." }\end{array}$ \\
\hline $\mathbf{H}_{9}$ & $\begin{array}{l}\text { "The chairman's tenure of the board has a statistically significant effect on R\&D } \\
\text { expenses." }\end{array}$ \\
\hline
\end{tabular}

The analysis regarding the effects of CGPs on R\&D expenses and innovation costs was conducted in line with the hypotheses established utilizing the relevant literature summarized in Table 3.

\section{FINDINGS}

The variable stationarities should be investigated before model estimation to avoid spurious regression problems due to models with non-stationary series in the panel data analysis. Therefore, the stationarities were examined with the Levin, Lin, and Chu (LLC) tests and assessed within the scope of first and second-generation unit root tests (Tatoğlu, 2017: 68). The relevant results indicated that all of the variables were stable at the level. The results are available in Appendix 1.

However, the Hausman test was applied to determine the panel data model for regression analysis between fixed-effect (FE) and random-effect (RE) models. The Hausman test results favored the FE estimator for Model 1 and 
the RE estimator for Models 2 and 3. The results are available in Appendix 2.

It is vital to examine the assumptions about autocorrelation, heteroscedasticity, and inter-unit correlation problems in fixed and random effects models. Facing one or more of such problems causes erroneous results regarding the predicted models (Ün, 2018: 75). After conducting the Bhargava et al. Durbin-Watson (DW) test, the obtained scores were below 2, which meant that there was an autocorrelation problem in the developed models (Tatoğlu, 2016: 238). Accordingly, it was observed that the DW test values in Table 7 were less than 2 , which was specified as the critical value for all 3 models. Therefore, it can be said that there was an autocorrelation problem in all 3 models. However, the modified Wald test of Model 1 revealed a heteroscedasticity problem in the designed model. Moreover, the Levene, Brown, and Forsythe tests applied for Models 2 and 3 indicated a heteroscedasticity problem in these models. Nevertheless, the Pesaran test results implied an inter-unit correlation problem for Model 2, but not for Models 1 and 3. The relevant test results are provided in Appendix 3.

The Arellano, Froot, and Rogers, and Driscoll and Kraay resistant estimators, commonly used in the literature, were chosen for performing the regression analyses of Models 1-3. These estimators were chosen because of their resistance to heteroscedasticity, autocorrelation, and inter-unit correlation problems, and ability to provide effective results (Tatoğlu, 2016: 276). Accordingly, the regression results are summarized in the following section. 
Table 4: Regression Results for Models

\begin{tabular}{|c|c|c|c|c|}
\hline \multicolumn{5}{|c|}{$\begin{array}{c}\text { - Model } 1 \text { - Dependent Variable: R\&D Year Range: } 2009 \text { - } 2017 \text { Number of Firms: } 76 \text { Total Number } 0 \\
\text { Observations: } 684\end{array}$} \\
\hline Variables & Efficiency & Std. Error & $\mathbf{t}$-Statistics & Probability Value \\
\hline IBM & 0.3863 & 0.2051 & 1.88 & $0.096^{* * *}$ \\
\hline GDBD & 1.5200 & 0.3652 & 4.16 & $0.003^{*}$ \\
\hline $\mathrm{CO}$ & -0.0004 & 0.0025 & -0.02 & 0.987 \\
\hline RD & -0.1323 & 0.1874 & -0.71 & 0.500 \\
\hline FMPBD & -0.6559 & 0.3294 & -1.99 & $0.082^{* * * *}$ \\
\hline BDO & -0.0089 & 0.0068 & -1.30 & 0.228 \\
\hline BS & 0.3444 & 0.1019 & 3.38 & $0.010^{*}$ \\
\hline CT & -0.0025 & 0.0397 & -0.06 & 0.950 \\
\hline BS & 0.4940 & 0.1126 & 4.39 & $0.002^{*}$ \\
\hline $\mathbf{O A}$ & 0.5303 & 0.1004 & 5.28 & $0.001^{*}$ \\
\hline Fixed Term & 2.0531 & 1.9822 & 1.04 & 0.331 \\
\hline \multicolumn{5}{|c|}{$R^{2}=0.2290 \quad F=18544.42 \quad$ Prob $>F=0.0000$} \\
\hline \multicolumn{5}{|c|}{$\begin{array}{l}\text { - Model } 2 \text { - Dependent Variable: Inv_Mlyt Year Range: } 2009 \text { - } 2017 \text { Number of Firms: } 22 \text { Total } \\
\text { Number of Observations: } 198\end{array}$} \\
\hline Variables & Efficiency & Std. Error & $\mathbf{t}$-Statistics & Probability Value \\
\hline BS & -0.2883 & 0.2462 & -1.17 & 0.275 \\
\hline BS & 0.9690 & 0.1666 & 5.82 & $0.000^{*}$ \\
\hline$\overline{\mathbf{O A}}$ & $\begin{array}{c}-0.6000 \\
\end{array}$ & 0.2026 & $\begin{array}{c}-2.96 \\
\end{array}$ & $0.018^{* * *}$ \\
\hline FMPBD & -0.8685 & 0.4365 & -1.99 & $0.082^{* * * *}$ \\
\hline BDO & 0.0063 & 0.0062 & 1.02 & 0.337 \\
\hline RD & 0.7909 & 0.3613 & 2.19 & $0.060^{* * * *}$ \\
\hline Fixed Term & -0.9942 & 3.0182 & -0.33 & 0.750 \\
\hline$R^{2}=0.4412$ & Wald ch & $=2460.15$ & rob $>\operatorname{chi}^{2}=0.0000$ & \\
\hline \multicolumn{5}{|c|}{$\begin{array}{c}\text { - Model } 3 \text { - Dependent Variable: R\&D Year Range: } 2009 \text { - } 2017 \text { Number of Firms: } 41 \text { Total Number } 0 \\
\text { Observations: } 369\end{array}$} \\
\hline Variables & Efficiency & Std. Error & t-Statistics & Probability Value \\
\hline BS & 0.2195 & 0.3643 & 0.60 & 0.547 \\
\hline CT & 0.1277 & 0.0767 & 1.66 & $0.096^{* * * *}$ \\
\hline BS & 0.6597 & 0.1557 & 4.24 & $0.000^{*}$ \\
\hline $\mathbf{O A}$ & $\begin{array}{l}-0.2689 \\
\end{array}$ & 0.4564 & -0.59 & 0.556 \\
\hline BMF & 0.3112 & 0.1440 & 2.16 & $0.031^{* * *}$ \\
\hline IBM & 0.5173 & 0.5130 & 1.01 & 0.313 \\
\hline GDBD & 2.2793 & 1.1640 & 1.96 & $0.050^{* * *}$ \\
\hline FMPBD & -0.5562 & 0.5126 & -1.09 & 0.278 \\
\hline BDO & -0.0155 & 0.0098 & -1.58 & 0.115 \\
\hline RD & -0.1229 & 0.3553 & -0.35 & 0.729 \\
\hline Fixed Term & $\begin{array}{l}-0.2920 \\
\end{array}$ & 2.5966 & -0.11 & 0.910 \\
\hline \multicolumn{3}{|l|}{$R^{2}=0.2446$} & $\mathrm{~b}>\mathrm{F}=\mathbf{0 . 0 0 0 0}$ & \\
\hline
\end{tabular}

First, the regression results of Model 1 revealed that the variables of the GDBD, BS, and OA and BS had a positive effect on R\&D, at a significance level of $1 \%$. Moreover, it was also found that the IBM had a positive on

Muhasebe ve Vergi Uygulamaları Dergisi 
$\mathrm{R} \& \mathrm{D}$, at a significance level of $10 \%$. Moreover, it was determined that the FMPBD had a negative effect on R\&D, at a significance level of $10 \%$.

The regression results of Model 2 showed that the BS had a positive effect on innovation costs, at a significance level of $1 \%$. Furthermore, it was determined that the RD had a positive effect on innovation costs, at a significance level of $10 \%$. Moreover, it was revealed that the OA had a negative effect on innovation costs, at a significance level of 5\%. Moreover, it was concluded from the previous table that the FMPBD had a negative effect on innovation costs, at a significance level of $10 \%$.

Last, the regression results of Model 3 indicate that the BS, BMF, and GDBD had a positive impact on R\&D expenses, at significance levels of $1 \%, 5 \%$, and $5 \%$, respectively. However, it was determined that the CT had a positive effect on $\mathrm{R} \& \mathrm{D}$ at a significance level of $10 \%$.

\subsection{Assessment}

It was found that the FMPBD had a negative effect on Models 1 and 2. Although it was not statistically significant, this condition was similar for Model 3. Thus, it can be argued that the increase in the number of foreign board members should reduce the R\&D expenses and innovation costs of enterprises.

Milliken and Martins (1996) also stated that the number of FMPBD negatively affected the potential innovation and R\&D activities. Similarly, Balsar1 et al. (2015) argued that broad racial diversity in management reduces the $R \& D$ and innovation intensity of enterprises due to business tendencies to prefer technology transfers instead of complementary inputs in their R\&D and innovation processes. Chen et al. (2016) concluded that ethnic differences in business management negatively affected the potential $\mathrm{R} \& \mathrm{D}$ and innovation activities in their studies on Taiwanese enterprises.

Another variable that had a positive effect in all of the research models was the BS, at a significance level of $1 \%$. The results indicated that the increase in an enterprise's total assets should positively affect future $R \& D$ and innovation costs. Recent studies have offered similar results (Choi et al. 2011; Chen, 2012; Kılıç and Keklik, 2012; Cebula and Rossi, 2015; Shapiro et al. 2015; Bobillo et al. 2017).

The empirical results showed that the BS had a positive effect on R\&D. It can be argued that the increase in the number of board members should have a positive effect on $\mathrm{R} \& \mathrm{D}$. This finding complied with the resource dependency theory. As the BS increases, the business accessibility and provides several advantages regarding substantial resource acquisitions. This result was similar to previous studies (Khanchel, 2007; Rabi et al. 2010; Shapiro et al. 2015; Ashwin et al. 2016). 
Moreover, the regression results indicated that the BS had a negative effect on innovation costs. This finding supported the arguments of the agency theory. This theory conceptualizes conflicts rooted in the board size, and difficulties in decision-making cause the performance deteriorations in enterprises. Therefore, an optimum limit on the number of board members is necessary for businesses. Torchia et al. (2011) and Zhaohui and Ding (2012) reached conclusions in line with this argument.

It was also discovered that the IBM had a positive effect on R\&D. This result was in accordance with the agency and resource dependency theory assertions. The presence of external board members is essential with regard to the board of directors' efficiency. However, it is arguable that the diversification of corporate culture will affect business performance positively. Black et al. (2006), Cornett et al. (2007), O'Connell and Cramer (2010), and Balsmeier et al. (2017) also reached results complimentary to this finding.

It can be asserted that talent pools created with gender diversity can contribute to an enterprise's performance. However, the presence of female members on the board of directors enables efficient results in decisionmaking regarding business activities by making the board more heterogeneous. Nevertheless, the CMB's communiqué in 2012 suggested that at least 1 female member should be on an enterprise's board of directors. The analysis of the impact regarding the GDBD has a positive effect on R\&D. This result was in agreement with those of previous studies (Pearce and Zahra 1991; Ararat et al. 2010; Torchia et al. 2011; LückerathRovers 2013).

Executives may be reluctant to set goals and produce projects with ambiguities in increasing shareholder profitability in businesses where the board members' capital share is high. The regression analysis regarding the effect of the $\mathrm{BDO}$ on $\mathrm{R} \& \mathrm{D}$ produced a positive correlation. It can be asserted that increases in the board members' capital share will be reflected as decreases in $R \& D$ expenses. However, it is arguable that this situation has a contrary effect on innovation costs. This difference is possibly rooted in the possibility of future economic benefits associated with intangible assets' encouraging effect on executives to have a positive attitude towards such investments. Moreover, the empirical results indicated that the BDO had a positive effect on innovation costs. The findings regarding board ownership were similar to the results obtained by previous research (Vafeas and Theodorou 1998; Beiner et al. 2006).

Another variable that examined the impact on $R \& D$ expenses and innovation costs was the RD. The regression results showed that the RD had a negative effect on R\&D. It was indicated that the duality in management will affect $R \& D$ expenses negatively. This situation was similar to the 
results obtained by Jermias (2007) and Blibech and Berraies (2018). Moreover, studies examining the CEO's role through the agent theory broadly accepted assertions that "the chairman of the board of directors and the general manager positions are executed by separate individuals increase the enterprise performance". Therefore, the duality is likely to positively affect business performance and innovation activities, particularly in the long-term context (Goegel and Jong 2017: 18). Nevertheless, it was observed that the RD had a positive effect on innovation costs. This finding supported the previously reached results by Goegel and Jong (2017).

Frequent board meetings increase the checks for business executives. Moreover, they also ensure that the executives receive information about the organization on time and have the opportunity to analyze the emergent problems rapidly. It can be asserted that the BMF held by the boards of directors during an activity cycle and the business performances are correlated (Al Hares et al. 2018: 3020). It was determined that the BMF had a positive effect on $R \& D$. Thus, it can be argued that the increase in the number of meetings held by the board of directors during an activity cycle will positively affect future R\&D activities. Noor (2011), Chen (2012), and Al-Najjar (2014) reached conclusions complimentary to this finding.

\section{CONCLUSION}

The last two decades have brought a significant increase in the number of studies regarding the impact of CGPs on business performance. However, this issue has been analyzed through cases from developed countries. Empirical studies on these topics with cases from developing countries like Turkey are only preliminary. There is merit in this state, as companies in these countries mostly address non-transparent explanations about the CG vision, and certain difficulties in the related data collection process.

Three models were created for this study. Models 1 and 3 focused on the effects of CGPs on R\&D expenses, while Model 2 analyzed the effects of these applications on innovation costs.

The analyses performed via Models 1 and 3 revealed that the BS, IBM, GDBD, CT, BMF, OA, and BS had a positive effect on the realized R\&D. However, it was determined that the FMPBD had a negative effect on R\&D.

The regression analysis performed via Model 2 indicated that the RD and BS had a positive effect on innovation costs. Moreover, it was determined that the FMPBD and OA had a negative effect on innovation costs.

Even in the businesses operating in Turkey with potentially improved CG visions, it is considered that CGPs are not implemented properly. Therefore, CG principles, transparency, accountability, fairness, and responsibility must be internalized, and a CG culture that will appeal to all departments of

Muhasebe ve Vergi Uygulamaları Dergisi 
an enterprise must be established to adapt a sustainable CG vision in enterprises. Regulators should develop several strategies and practices to design a CG vision that can be suitable for business culture.

Particular sectoral distinctions can be applied in the data collection process for future studies, and alternative indicators of CGPs can be utilized.

\section{REFERENCES}

Aghion, P., Van, R. J. ve Zingales L. (2013). Innovation and Institutional Ownership. The American Economic Review, 103(1): 277-304.

Ahlering, B. ve Deakin, S. (2007). Labor Regulation, Corporate Governance, and Legal Origin: A Case of Institutional Complementarity?. Law and Society Review, 41(4): 865-908.

Ahmed, E. ve Hamdan, A. (2015). The Impact Of Corporate Governance On Firm Performance: Evidence From Bahrain Stock Exchange. European Journal of Business and Innovation Research, 3(5): 25-48.

Akdoğan N, Gülhan O. ve Aktaş M. (2017). The Relationship Between Corporate Social Responsibility Reporting and Corporate Governance: Evidence from Turkish Banking Sector. Journal of Modern Accounting and Auditing, 13:181-195.

Al Hares, A., Ntim, C., Al-Hares, O. ve Al Abed, R. (2018). Frequency of Board Meetings and R\&D Investment Strategy: Evidence from OECD Countries, Theoretical Economics Letters, 8: 3016-3033.

Al-Najjar, B. (2014). Corporate Governance, Tourism Growth and Firm Performance: Evidence From Publicly Listed Tourism Firms in Five Middle Eastern Countries. Tourism Management, 42: 342-351.

AlQudah, A.M., Azzam, M.J., Aleqab, M.M. ve Shakhatreh, M.Z. (2019). The Impact of Board of Directors Characteristics on Banks Performance: Evidence From Jordan. Academy of Accounting and Financial Studies Journal, 23(2): 1 - 16.

Ararat, M. A., Çetin M. ve Tansel A. (2010). Impact of Board Diversity on Boards's Monitoring Intensity and Firm Performance: Evidence From The Istanbul Stock Exchange. 17th Annual Conference of The Multinational Finance Society, 1- 33, New Jersey: Multinational Finance Society.

Ashwin, A.S., Krishnan, R.T. ve George, R. (2016). Board Characteristics, Financial Slack and R\&D Investments An Empirical Analysis of the Indian Pharmaceutical Industry. International Studies of Management \& Organization, 46: 8-23.

Muhasebe ve Vergi Uygulamaları Dergisi 
Atılgan, Ö. (2017). Yönetim Kurulu Büyüklüğü, Bağımsız Üye Oranı ve Kadın Üye Oranı ile Finansal Performans İlişkisi. Dokuz Eylül Üniversitesi İktisadi ve İdari Bilimler Fakültesi Dergisi, 32(2): 315-354.

Aygün, M., ve İç, S. (2010). Genel Müdürün Aynı Zamanda Yönetim Kurulu Üyesi Olması Firma Performansını Etkiler mi?. Muhasebe ve Finansman Dergisi, 47: 192-201.

Aytekin, S. ve İbiş, A. (2014). Mülkiyet Yapısının İşletmelerin Finansal Performansı Üzerindeki Etkilerinin Değerlendirilmesi: BİST Metal Eşya, Makina Endeksi (XMESY) Üzerinde Bir Uygulama. Dumlupinar Üniversitesi Sosyal Bilimler Dergisi, 40: 119 - 130.

Balsarı, Ç. K., Varan, S. ve Özkan, S. (2015). Impact of Foreign Ownership on Innovation. Journal of Economics and Management, 20(A): 86-96.

Balsmeier, B., Lee F. ve Gustavo M. (2017). Independent Boards and Innovation. Journal of Financial Economics, 123: 536-557.

Baraco, D.G. ve Brown, A.M. (2008). Corporate Social Reporting and Board Representation: Evidence From The Kenyan Banking Sector. Journal of Management and Governance, 12(4):309-324.

Barker, V.L. ve Mueller, G.C. (2002). CEO Characteristics and Firm R\&D Spending. Management Science, 48(6): 782-801.

Başaran, S. D. ve Keleş, S. (2015). Yenilikçi Kimdir? Öğretmenlerin Yenilikçilik Düzeylerinin İncelenmesi. Hacettepe Üniversitesi Eğitim Fakültesi Dergisi, 30 (4): 106-118.

Beiner, S., Drobetz, W., Schmid, M. M. ve Zimmermann, H. (2006). An Integrated Framework of Corporate Governance and Firm Valuation. European Financial Management, 12: 249- 283.

Ben-Amar, W., Chang, M. ve Mcllkenny, P. (2017). Board Gender Diversity and Corporate Response To Sustainability Initiatives: Evidence From The Carbon Disclosure Project. Journal of Business Ethics, 142(2): 369-383.

Bentz, F. (1997). Managing Technological Innovation: Competitive Advantage from Change. New York: John Wiley \& Sons Ltd.

Bhagat, S. ve Bolton, B. (2013). Director Ownership, Governance, and Performance. Journal of Financial and Quantitative Analysis, 48(1): 105135.

Black, B. S., Jang H. ve Kim, W. (2006). Does Corporate Governance Predict Firms' Market Values? Evidence from Korea. Journal of Law, Economics and Organization, 22: 366- 413.

Muhasebe ve Vergi Uygulamaları Dergisi 
Blibech, N. ve Berraies, S. (2018). The Impact of CEO' Duality and Board's Size and Independence on Firms' Innovation and Financial Performance. Journal of Business Management and Economics, 9(1): 22-29.

Bobillo, A., Rodríguez-Sanz, J.A. ve Tejerina-Gaite, F. (2017). Corporate Governance Drivers of Firm Innovation Capacity. Rev Int Econ, 1-21.

Brossard, O., Lavigne S. ve Sakinc M.E. (2013). Ownership Structures and R\&D in Europe: The Good Institutional Investors, the Bad and Ugly Impatient Shareholders. Industrial and Corporate Change, 22(4): 10311068.

Cebula, R.J. ve Rossi, F. (2015). Ownership Structure and R\&D: An Empirical Analysis of Italian Listed Companies. PSL Quarterly Review, 68(275): 297-325.

Chang, R.D., Chang, Y.W., Chang, C.P. ve Hu, F. (2008). The Effects of Corporate Governance Mechanisms and Investment Opportunity Set on Firm Performance. Corporate Ownership \& Control, 5(4): 135 - 148.

Chau, G. ve Gray, S.J. (2010). Family Ownership, Board Independence and Voluntary Disclosure: Evidence from Hong Kong. Journal of International Accounting, Auditing and Taxation, 19: 93-109.

Chen, H.L. (2012). Board Characteristics and R\&D Investment: Evidence from Taiwan's Electronics Industry. Advances in Management \& Applied Economics, 2(4): 161-170.

Chen, C.J., Lin, S.W., Lin, Y.H. ve Hsiao, Y.C. (2016). Ownership Structure, Independent Board Members and Innovation Performance: A Contingency Perspective. Journal of Business Research, 69: 3371-3379.

Cheng, E.C.M. ve Courtenay, S.M. (2006). Board Composition, Regulatory Regime and Voluntary Disclosure. The International Journal of Accounting, 41(3):262 - 289.

Choi, S., Lee, S. ve Williams, C. (2011.) Ownership and Firm Innovation in a Transition Economy: Evidence From China. Research Policy, 40(3): 441452.

Choi, S.B., Il Park, B. ve Hong, P. (2012). Does Ownership Structure Matter for Firm Technological Innovation Performance?. Corporate Governance: An International Review, 20(3): 267- 288.

Chou, T.K. (2017). The Effects of Board Characteristics and Ownership Structure on R\&D Investment. Proceedings of 8th Global Business Research Conference, 13 - 14 July 2017, LIUC-Universita Cattaneo, Milan, Italy.

Muhasebe ve Vergi Uygulamaları Dergisi 
Coles, J. W., McWilliams, V. B. ve Sen, N. (2001). An Examination of the Relationship of Governance Mechanisms to Performance. Journal of Management, 27 (1): 23-50.

Cornett, M. M., Marcus A. J., Saunders, A. \& Tehranian, H. (2007). The Impact of Institutional Ownership on Corporate Operating Performance. Journal of Banking \& Finance, 31: 1771- 1794.

Cucculelli, M. (2018). Firm Age and The Probability of Product Innovation. Do CEO Tenure and Product Tenure Matter?. Journal of Evolutionary Economics, 28(1): 153-179.

Cuervo, A. (2002). Corporate Governance Mechanisms: A Plea for Less Code of Good Governance and More Market Control. Corporate Governance: An International Review, 10(2): 84-93.

Dainien, R. ve Dagiliene, L. (2014). Accounting-Based Valuation of Innovation: Challenges and Perspectives. Procedia - Social and Behavioral Sciences, 156 (2014): 589 - 593.

Demsetz, H. Villalonga, B. (2001). Ownership Structure and Corporate Performance. Journal of Corporate Finance, 7(2001): 209-233.

Doğan, M., Elitaş, B.L., Ağca, V. ve Ögel, S. (2013). The Impact of CEO Duality on Firm Performance: Evidence From Turkey. International Journal of Business and Social Science, 4(2): 149-155.

Doğan, M. ve Tiryakioğlu, M. (2018). Sahiplik Yapısı ve Ar-Ge Harcamaları: Borsa İstanbul Örneği. Uluslararası Yönetim İktisat ve İsletme Dergisi, 14(1): .67-79.

Donaldson, L. ve Davis, J. H. (1991). Stewardship Theory or Agency Theory: CEO Governance and Shareholder Returns. Australian Journal of Management, 16 (1): 49- 64.

Eng, L.L. ve Shackell, M. (2001). The Implications of Long-Term Performance Plans and Institutional Ownership for Firms' Research and Development Investments. Journal of Accounting, Auditing and Finance, 16(2): 117-139.

Eng, L. L. ve Mak, Y. T. (2003). Corporate Governance and Voluntary Disclosure. Journal of Accounting and Public Policy, 22(4): 325-345.

Fauzi, F. ve Locke, S. (2012). Board Structure, Ownership Structure and Firm Performance: A Study of New Zealand Listed-Firms. AAMJAF, 8(2): 43-67.

Fidancı, N. (2017). Araştırma, Geliştirme (Ar-Ge) ve Tasarım Harcamalarının Vergisel Düzenlemeler ve Teşvikler Çerçevesinde İncelenmesi ve Muhasebeleştirilmesi. Muhasebe ve Vergi Uygulamaları Dergisi Şubat 2017, 10 (5): 69-90.

Muhasebe ve Vergi Uygulamaları Dergisi 
Finkelstein, S., ve D’Aveni, R. (1994). CEO Duality as a Double-Edged Sword: How Boards of Directors Balance Entrenchment Avoidance and Unity Of Command. Academy of Management Journal, 37: 1079-1108.

Forbes, D.P. ve Milliken F.J. (1999). Cognition and Corporate Governance: Understanding Boards of Directors as Strategic Decision-Making Groups. Academic Management Review, 24(3) : 489-505.

Galia, F. ve Zenou, E. (2012). Board Composition and Forms Of Innovation: Does Diversity Make a Difference?. European Journal of International Management, 6(6): 630-650.

García, C.Q. ve Velasco, C.A.B. (2016). Gender Diversity in Top Management Teams and Innovation Capabilities: The Initial Public Offerings of Biotechnology Firms. Long Range Planning, 49 (2016): 507518.

Goegel, L. ve Jong, P. (2017). Wearing Two Hats: CEO Duality, Risk, Innovation, and Firm Performance in the IT Industry. Review of Contemporary Business Research, 6(2): 16-25.

Golden, B. R. ve Zajac, E. J. (2001). When Will Boards Influence Strategy? Inclination Power 5 Strategic Change. Strategic Management Journal, 22: 1087-1111.

Graves, S.B. ve Waddock S.A. (1990). Institutional Ownership and Control: Implications for Long-Term Corporate Strategy. The Executive, 4(1): 75-83.

Gunnarsson, J., Cikusa, N. ve Hansen, A.D. (2017). Impact of Innovation and Places on Corporate Governance the Case of Wind Turbine Production. Journal of Advances in Economics and Finance, 2(1): 9-28.

Gürbüz, A. O. ve Ergincan, Y. (2004). Kurumsal Yönetim: Türkiye'deki Durumu ve Geliştirilmesine Yönelik Öneriler. İstanbul: Literatür Yayınları.

Jermias, J. (2007). The Effects of Corporate Governance on The Relationship Between Innovative Efforts and Performance. Eur. Accounting. Rev., 16(4): 827-854.

Jiménez, J.M.R. ve Fuentes, M.M.F. (2015). Management Capabilities, Innovation, and Gender Diversity In The Top Management Team: An Empirical Analysis In Technology-Based SMEs. BRQ Business Research Quarterly, 19: 107-121.

Juhmani, O. (2013). Ownership Structure and Corporate Voluntary Disclosure: Evidence from Bahrain. International Journal of Accounting and Financial Reporting, 3(2): 133-148.

Kara, E., Erdur, D. ve Karabiyık, L. (2015). Effects of Corporate Governance Level on The Financial Performance of Companies: A

Muhasebe ve Vergi Uygulamaları Dergisi 
Research on BIST Corporate Governance Index (XKURY). Ege Academic Review, 15(2): 265-274.

Khanchel, I. (2007). Corporate Governance: Measurement and Determnant Analyss. Manageral Audtng Journal, 22(8): 740-760.

Kılıç, M. (2014). Yönetim Kurulu Yapısının İşletme Performansına Etkisi: Türkiye'de Bir Uygulama. Muhasebe Bilim Dünyası Dergisi, 16(3): 33-56.

Kılıç, R. ve Keklik, B. (2012). KOBİ’lerde Genel Firma Özelliklerinin İnovasyon Uygulamalarına Etkisi: Balıkesir İlinde Bir Araştırma. Erciyes Üniversitesi İktisadi ve İdari Bilimler Fakültesi Dergisi, 39(Ocak-Haziran): 93-118.

K1lıç, M. ve Kuzey, C. (2019). The Effect of Corporate Governance on Carbon Emission Disclosures: Evidence From Turkey. International Journal of Climate Change Strategies and Management, 11(1): 35-53.

Kocamış, T.U. ve Güngör, A. (2014). Türkiye'de Ar-Ge Harcamaları ve Teknoloji Sektöründe Ar-Ge Giderlerinin Kârlılık Üzerine Etkisi: Borsa İstanbul Uygulamas1. Maliye Dergisi, 166(Ocak-Haziran): 127-138.

Kostellou, S. ve Tsakiri, A. (2010). R\&D Spending and Subsequent Market Returns. Does Expensing Versus Capitalizing Matter for European Firms?. A dissertation submitted for the partial fulfillment for the degree of MSc in Management.https://www.ihu.edu.gr/gateway/files/document/dissertations/ Kostellou-Tsakiri.pdf

L'Huillier, B.M. (2014). What Does "Corporate Governance" Actually Mean?. Corporate Governance International Journal of Business in Society, 14(3): 300-319.

Labelle, R., Francoeur, C., ve Lakhal, F. (2015). To Regulate or Not to Regulate? Early Evidence on the Means Used Around the World to Promote Gender Diversity in the Boardroom. Gender,Work and Organization, 22(4): 339-363.

Labunska, S., Petrova, M. ve Prokopishyna, O. (2017). Asset and Cost Management for Innovation Activity. Economic Annals-XXI, 165(5-6): 1318.

Laksmana, I. (2008). Corporate Board Governance and Voluntary Disclosure of Executive Compensation Practices. Contemporary Accounting Research, 25 (4): 1147-1182.

Lee, S. (2012). Financial Determinants of Corporate R\&D Investment in Korea. Asian Economic Journal, 26(2): 119-135.

Lee, M. (2015). Impact of Corporate Governance on Research and Development Investment in the Pharmaceutical Industry in South Korea. Osong Public Health Res Perspect, 6(4): 249-255.

Muhasebe ve Vergi Uygulamaları Dergisi 
Liao, L., Luo, L.,ve Tang, Q. (2015). Gender Diversity, Board Independence, Environmental Committee and Greenhouse Gas Disclosure. British Accounting Review, 47(4): 409-424.

Lin, C.Y. ve Ho, Y.H. (2007). Technological Innovation for China's Logistics Industry. Journal of Technology Management \& Innovation, 2(4): $1-19$.

Littkemann, J. (1996). Dealing With Innovation Costs in Financial Accounting: An International Comparison. Manuskripte aus den Instituten für Betriebswirtschaftslehre der Universität Kiel, No. 392, Universität Kiel, Institut für Betriebswirtschaftslehre, Kiel. http://hdl.handle.net/10419/181068

Luo, Y. (2005). Corporate Governance and Accountability in Multinational Enterprises: Concepts and Agenda. Journal of International Management, 11 (1): 1-18.

Lückerath-Rovers, M. (2013). Women on Boards and Firm Performance. Journal of Management and Governance, 17(2): 491-509.

Makkonen, T., Williams, A.M. ve Habersetzer, A. (2018). Foreign Board Members and Firm Innovativeness: An Exploratory Analysis For Setting A Research Agenda. Corporate Governance: The International Journal of Business in Society, 1-32.

Mallette, P. ve Fowler, K. L. (1992). Effects of Board Composition and Stock Ownership on the Adoption of 'Poison Pills. Academy of Management Journal, 35 (5): 1010-1035.

Mat Rabi, N., Zulkafli, A. H., ve Haat, C.M.H. (2010). Corporate Governance, Innovation Investment and Firm Performance: Evidence from Malaysian Public Listed Companies. Journal of Management, Economia. Seria Management, 13(2): 225-239.

Mezghanni, B.S. (2010). How Ceo Attributes Affect Firm R\&D Spending? New Evidence From A Panel Of French Firms [Bildiri]. Crises et nouvelles problématiques de la Valeur, May1s 2010, Nice, France.

Midavaine, J., Dolfsma, W. ve Aalbers, R. (2016). Board Diversity and R\&D Investment. Management Decision, 54(3): 558-569.

Miller, T. ve Triana, A.C. (2009). Demographic Diversity in the Boardroom: Mediators of the Board Diversity-Firm Performance Relationship. Journal of Management Studies, 46(5): 755-786.

Milliken, F. J. ve Martins, L.L. (1996). Searching for Common Threads: Understanding The Multiple Effects of Diversity in Organizational Groups. The Academy of Management Review, 21 (2): 402-433.

Muhasebe ve Vergi Uygulamaları Dergisi 
Minetti R., Murro P. ve Paiella M. (2015). Ownership Structure, Governance, and Innovation. European Economic Review, 80(2015): 165193.

Muhasebe Sistemi Uygulama Genel Tebliği (1992). T.C.Resmi Gazete,21447, 12 Aralik 1992.

Musteen, M., Barker, V.L. ve Baeten, V.L. (2006). CEO Attributes Associated With Attitude Toward Change: The Direct and Moderating Effects of CEO Tenure. Journal of Business Research, 59(5): 604-612.

Müller, V.O. (2014). The Impact of Board Composition on the Financial Performance of FTSE100 Constituents. Procedia - Social and Behavioral Sciences, 109(2014): 969 - 975.

Noor, M. A. M. (2011). The Effect of Implementation of Malaysia Code of Corporate Governance (MCCG) 2007 on Corporate Governance Attributes and Financial Performance. University Utara Malaysia, Ph. D. DPA Dissertation, Malezya.

Ntim, C.G. ve Osei, K.A. (2011). The Impact of Corporate Board Meetings on Corporate Performance in South Africa. African Review of Economics and Finance, 2(2): 83-103.

O'Connell, V. ve Cramer, N. (2010). The Relationship Between Firm Performance and Board Characteristics In Ireland. European Management Journal, 28: 387- 399.

Ocak, M. ve Özden, E. A. (2017). Yönetim Kurulu Toplantı Sayısını Etkileyen Faktörler: Borsa İstanbul'a İlişkin Bulgular. Business and Economics Research Journal, 8(2): 217-230.

OECD (2015). G20/OECD Principles of Corporate Governance. Paris: OECD Publishing.

OECD. (1999). Principles of Corporate Governance. Paris: OECD.

Okere, W., Eluya, D.F., Lawal, A.I., Oyebisi, I., Eseyin, O., Popoola, O. ve Awe, T.E. (2019). Foreign Expatriates on Board and Financial Performance: A Study of Listed Deposit Money Banks in Nigeria. The Journal of Social Sciences Research, 5(2): 418-423.

Østergaard, C. R., Timmermans, B., ve Kristinsson, K. (2011). Does a Different View Create Something New? The Effect Of Employee Diversity On Innovation. Research Policy, 40(3): 500- 509.

Otluoğlu, E., Sarı, E. S. ve Otluoğlu, K. Ö. Ç. (2016). Yönetim Kurulu Çeşitliliğinin Finansal Performansa Etkisi: BIST 100 Üzerine Bir Araştırma. Uluslararası Sosyal Araştırmalar Dergisi, 9(46): 749-758.

Muhasebe ve Vergi Uygulamaları Dergisi 
Pearce, J. A. ve Zahra, S. A. (1991). The Relative Power of CEOs and Boards of Directors: Associations with Corporate Performance. Strategic Management Journal, 12(2): 135- 153.

Pfeifer, C. ve Wagner, J. (2012). Is Innovative Firm Behavior Correlated With Age and Gender Composition of The Workforce? Evidence From A New Type of Data for German Enterprises. Journal for Labour Market Research,47(3): 1-9.

Rechner, P. L. ve Dalton, D. R. (1991). CEO Duality and Organizational Performance: A ongitudinal Analysis. Strategic Management Journal, 12 (2): 155-160.

Reed, D. (2002). Corporate Governance Reforms in Developing Countries. Journal of Business Ethics, 37: 223-247.

Ren, H., Chandrasekar, K. ve Li, B. (2012). Moderating Effects of Board and Managerial Incentive on the Relationship between R\&D Investment and Firm Performance Evidence from Listed Manufacturing Firms in China. The Journal of International Management Studies, 7(1): 41-55.

Rupley, K.H., Brown, D. ve Marshall, R.S. (2012). Governance, Media and The Quality of Environmental Disclosure. Journal of Accounting and Public Policy, 31: 610-640.

Samaha, K., Dahawy, K., Hussainey, K. ve Stapleton, P. (2012). The Extent of Corporate Governance Disclosure and Its Determinants in a Developing Market: The Case of Egypt. Advances in Accounting, incorporating Advances in International Accounting, 28 (2012): 168-178.

Setayesh, M.H., Rezaei, G. ve Kazemnezhad, R. (2016). Corporate Governance, Investment in Research and Development and Company Performance: A Data Envelopment Analysis Approach Based on Data from a Developing Country. International Journal of Economics and Financial Issues, 6(3): 1114-1122.

Shapiro, D., Tang, Y., Wang, M. ve Zhang, W. (2015). The Effects of Corporate Governance on the Innovation Performance of Chinese SMEs. Journal of Chinese Economic and Business Studies, 13(4): 311-335.

Singh, D.A. ve Gaur, A.S. (2013). Governance Structure, Innovation and Internationalization: Evidence From India. Journal of International Management, 19(3): 300-309.

Singh, M. (2015). Firm R\&D Strategies Impact of Corporate Governance. Journal of Applied Business and Economics, 17(3): 35-44.

Soliman, M.M., Ragap, A.A. ve Eldin, M.B. (2014). Board Composition, Ownership Structure and Voluntary Disclosure: An Empirical Study of The

Muhasebe ve Vergi Uygulamaları Dergisi 
EFFECT OF CORPORATE GOVERNANCE PRACTICES ON R\&D AND INNOVATION COSTS: A CASE STUDY ON BORSA İSTANBUL

Listed Companies In Egypt. Corporate Ownership \& Control, 11(2): 415426.

Sternberg, E. (1998). Corporate Governance: Accountability in The Marketplace. London: The Institute of Economic Affairs.

Sunday, O. ve Godvin, O. (2017). Effects of Board Globalizing on Financial Performance of Banks in Nigeria. International Journal of Academic Research in Accounting, Finance and Management Sciences, 7(4):1-10.

Şahin, M. (2004). Üretim Sistemlerinin Tasarım Kuruluş ve İşleyişi, Genel İsletme. Eskişehir: Anadolu Üniversitesi Yayınları.

Talavera, O., Yin, S., ve Zhang, M. (2018). Age Diversity, Directors' Personal Values, and Bank Performance. International Review of Financial Analysis, 55: 60-79.

Talke, K., Salomo, S. ve Rost, K. (2010). How Top Management Team Diversity Affects Innovativeness and Performance Via The Strategic Choice To Focus On Innovation Fields. Research Policy, 39: 907-918.

Taşkın, F. D. ve Mandacı, P. E. (2017). Şirket Yönetim Kurulundaki Kadın Üyelerin Firma Performansına Etkisi. İşletme Fakültesi Dergisi, 18(1): 2945.

Tatoğlu, F.Y. (2016). Panel Veri Ekonometrisi. İstanbul: Beta Yayın.

Tatoğlu, F.Y. (2017). Panel Zaman Serileri Analizi. İstanbul: Beta Yayın.

Terjesen, S., Couto, E.B. ve Francisco, P.M. (2016). Does The Presence Of Independent and Female Directors Impact Firm Performance? A MultiCountry Study Of Board Diversity. Journal of Management \& Governance, 20(3): 447-483.

Teruel, M., Parra, M. D., ve Segarra, A. (2015). Gender Diversity and Innovation in Manufacturing and Service Firms. Working Paper, Universitat Rovira I Virgili Department D'economia.

Torchia, M., Calabrò, A. ve Huse, M. (2011). Women Directors on Corporate Boards: From Tokenism To Critical Mass. Journal of Business Ethics, 102(2): 299-317.

Tribo, J., Berrone, P. ve Surroca, J. (2007). Do The Type and Number of Blockholders Influence R\&D Investments? New Evidence from Spain. Corporate Governance: An International Review, 15(5): 828-842.

Ujunwa, A., Nwakoby, I. ve Ugbam, C.O. (2012). Corporate Board Diversity and Firm Performance: Evidence From Nigeria. Corporate Ownership and Control, 9(2): 216-223.

Muhasebe ve Vergi Uygulamaları Dergisi 
Uyar, A., Kılıç, M. ve Bayyurt, N. (2013). Association Between Firm Characteristics and Corporate Voluntary Disclosure: Evidence From Turkish Listed Companies. Intangible Capital, 9(4): 1080-1112.

Ün, T. (2018). Uygulamall Panel Veri Ekonometrisi. İstanbul: Der Yayınları.

Vafeas, N. ve Theodorou, E. (1998). The Relationship Between Board Structure and Firm Performance in the UK. The British Accounting Review, 30: 383-407.

Vafeas, N. (2003). Length of Board Tenure and Outside Director Independence. Journal of Business Finance and Accounting, 30(2003): 1043-1064.

Yangfan, T. (2015). Ownership Concentration and Innovation: Empirical Examination From China. Hong Kong Baptist Üniversitesi, An Honours Degree Project Submitted to the School of Business in Partial Fulfillment of the Graduation Requirement for the Degree of Bachelor of Business Administration, Accounting Concentration, Hong Kong.

Zhaohui, Z. ve Ding, W. (2012). The Board Structure and R\&D Investment A Study on the Chinese Listed IT Companies [Bildiri]. 2012 International Symposium on Management of Technology (ISMOT), 8-9 Nov. 2012, Hangzhou, China. 
EFFECT OF CORPORATE GOVERNANCE PRACTICES ON R\&D AND INNOVATION COSTS: A CASE STUDY ON BORSA İSTANBUL

APPENDIX

Appendix 1: Unit Root Tests

\begin{tabular}{|c|c|c|c|c|}
\hline & \multicolumn{2}{|c|}{ First Generation LLC Test } & \multicolumn{2}{|c|}{$\begin{array}{l}\text { Second Generation LLC Test (Difference } \\
\text { From Horizontal Cross Section Means) }\end{array}$} \\
\hline Variables & $\begin{array}{l}\text { Constant (p- } \\
\text { value) }\end{array}$ & $\begin{array}{c}\text { Constant \& } \\
\text { Trend } \\
\text { (p-value) }\end{array}$ & Constant (p-value) & $\begin{array}{c}\text { Constant \& } \\
\text { Trend } \\
\text { (p-value) }\end{array}$ \\
\hline \multicolumn{5}{|c|}{ Model 1} \\
\hline R\&D & $0.000^{*}$ & $0.000^{*}$ & $0.000^{*}$ & $0.000^{*}$ \\
\hline$\overline{\mathrm{BS}}$ & $0.000^{*}$ & $0.000^{*}$ & $0.000^{*}$ & $0.000^{*}$ \\
\hline CT & $0.000^{*}$ & $0.030^{* * *}$ & $0.000^{*}$ & $0.000^{*}$ \\
\hline BS & $0.000^{*}$ & $0.000^{*}$ & $0.000^{*}$ & $0.000^{*}$ \\
\hline OA & $0.000^{*}$ & $0.000^{*}$ & $0.000^{*}$ & $0.000^{*}$ \\
\hline IBM & $0.000^{*}$ & $0.000^{*}$ & $0.000^{*}$ & $0.000^{*}$ \\
\hline GDBD & $0.000^{*}$ & $0.000^{*}$ & $0.000^{*}$ & $0.000^{*}$ \\
\hline $\mathrm{CO}$ & $0.000^{*}$ & $0.000^{*}$ & $0.000^{*}$ & $0.000^{*}$ \\
\hline FMPBD & 0.462 & 0.307 & $0.000^{*}$ & $0.000^{*}$ \\
\hline $\mathrm{BDO}$ & $0.000^{*}$ & $0.000^{*}$ & $0.000^{*}$ & $0.000^{*}$ \\
\hline \multicolumn{5}{|c|}{ Model 2} \\
\hline Inv_Mlyt & $0.000^{*}$ & $0.000^{*}$ & $0.088^{* * * *}$ & $0.000^{*}$ \\
\hline BS & $0.000^{*}$ & $0.000^{*}$ & $0.000^{*}$ & $0.000^{*}$ \\
\hline BS & $0.269^{*}$ & $0.000^{*}$ & $0.000^{*}$ & $0.000^{*}$ \\
\hline OA & $0.000^{*}$ & $0.000^{*}$ & $0.000^{*}$ & $0.000^{*}$ \\
\hline FMPBD & $0.000^{*}$ & $0.000^{*}$ & $0.003^{*}$ & $0.000^{*}$ \\
\hline BDO & $0.000^{*}$ & $0.000^{*}$ & $0.000^{*}$ & $0.000^{*}$ \\
\hline \multicolumn{5}{|c|}{ Model 3} \\
\hline R\&D & $0.0000^{*}$ & $0.0000^{*}$ & $0.0000^{*}$ & $0.0000^{*}$ \\
\hline BS & $0.0000^{*}$ & $0.0000^{*}$ & $0.0000^{*}$ & $0.0000^{*}$ \\
\hline CT & $0.0000^{*}$ & 0.476 & $0.0000^{*}$ & $0.0000^{*}$ \\
\hline BS & $0.0136^{* *}$ & $0.0000^{*}$ & $0.0000^{*}$ & $0.0000^{*}$ \\
\hline$\overline{\mathrm{OA}}$ & $0.0000^{*}$ & $0.0000^{*}$ & $0.0000^{*}$ & $0.0000^{*}$ \\
\hline BMF & $0.0000^{*}$ & $0.0000^{*}$ & $0.0000^{*}$ & $0.0000^{*}$ \\
\hline IBM & $0.0000^{*}$ & $0.0000^{*}$ & $\overline{0.0000^{*}}$ & $0.0000^{*}$ \\
\hline GDBD & $0.0140^{* *}$ & $0.0000^{*}$ & $0.0000^{*}$ & $0.0000^{*}$ \\
\hline FMPBD & $0.0000^{*}$ & 0.2508 & $0.0000^{*}$ & $0.0000^{*}$ \\
\hline $\mathrm{CO}$ & $0.0000^{*}$ & $0.0000^{*}$ & $0.0000^{*}$ & $0.0000^{*}$ \\
\hline
\end{tabular}

Muhasebe ve Vergi Uygulamaları Dergisi 
Appendix 2: Hausman Test

\begin{tabular}{|c|c|}
\hline Models & Probability Values \\
\hline Model 1 & $0.005^{*}$ \\
\hline \hline Model 2 & 0.783 \\
\hline \hline Model 3 & 0.146 \\
\hline \hline Note: $(*),(* *)$ and $(* * *)$ signs indicate significance level at 1\%, 5\% and 10\%, respectively. \\
\hline
\end{tabular}

Appendix 3: Test Results on Assumptions

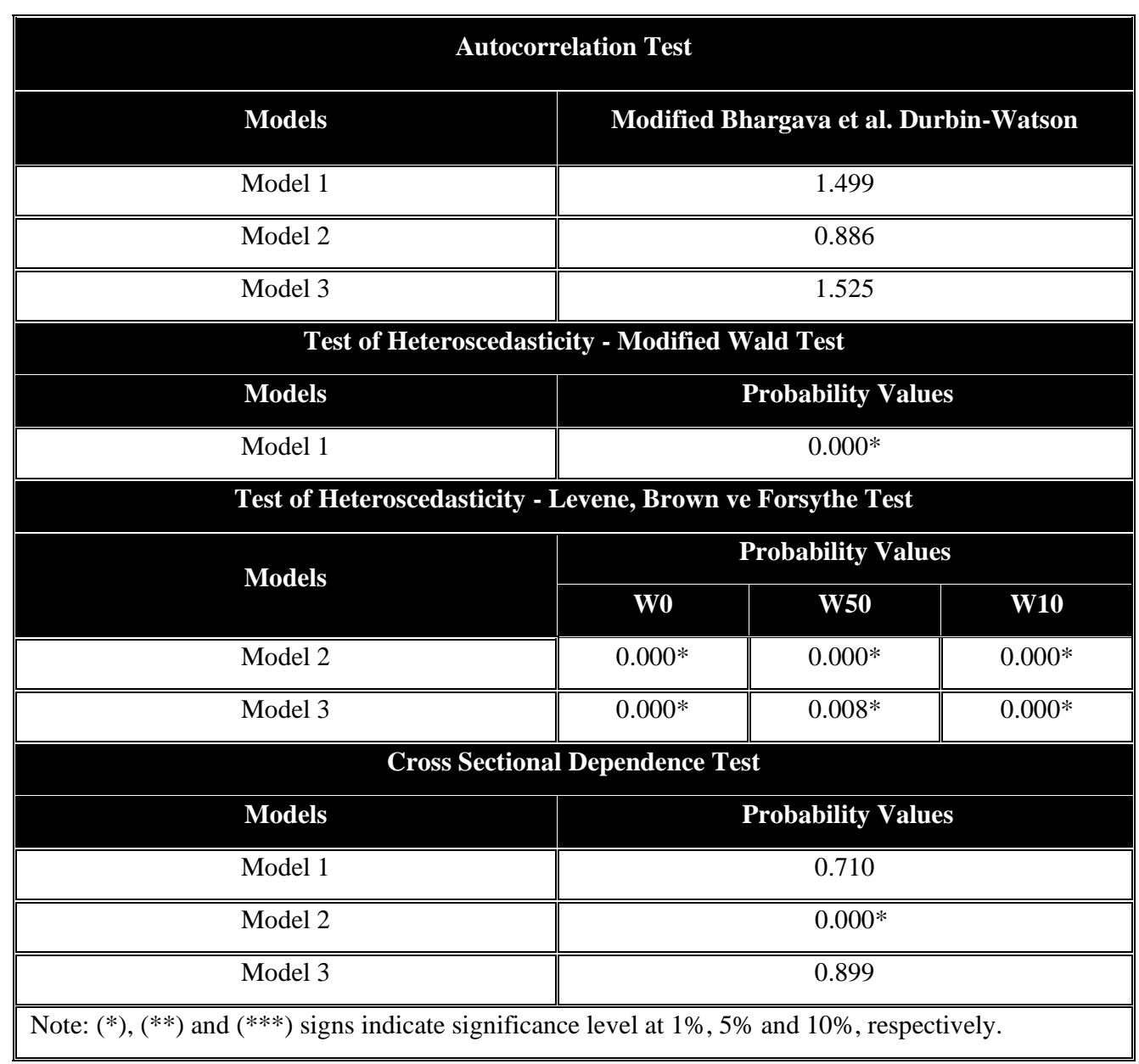

Muhasebe ve Vergi Uygulamaları Dergisi 